\title{
Particle clearance and yield in relation to bacterioplankton and suspended particulate availability in estuarine and open coast populations of the mussel Mytilus edulis
}

\author{
M. I. Lucas ${ }^{1}$, R. C. Newell ${ }^{2}$, S. E. Shumway ${ }^{3}$, L. J. Seiderer ${ }^{1}$ \& R. Bally ${ }^{1}$ \\ ${ }^{1}$ Marine Biology Research Institute, Department of Zoology, University of Cape Town, Rondebosch 7700, South Africa \\ ${ }^{2}$ Institute for Marine Environmental Research, Prospect Place, Plymouth PL1 3DH, United Kingdom \\ ${ }^{3}$ Department of Marine Resources and Bigelow Laboratory for Ocean Sciences, West Boothbay Harbor, Maine 04575, USA
}

\begin{abstract}
Measurements were made of resource availability and the filtration rate and particle retention efficiency of mussels Mytilus edulis L. from an estuarine site on the River Lynher and from an open coastal site at Whitsand Bay, Cornwall, UK. Small cocci of $0.25 \mu \mathrm{m}$, large cocci of $0.56 \mu \mathrm{m}$ and small rods of $0.725 \mu \mathrm{m}$ mean spherical diameter comprised $87 \%$ of the free-living bacterial population at Whitsand Bay and $86 \%$ in the Lynher estuary during September 1984. Free-living bacteria represented only $5 \%$ of the carbon and 9.7 and $11.3 \%$ respectively of the nitrogen potentially available for exploitation as a food resource in the water column at the estuarine and open coast sites. Weightspecific clearance rate of particles $>12.7 \mu \mathrm{m}$ diameter by $M$. edulis from the Lynher estuary was approximately $2.5 \mathrm{I} \mathrm{g}^{-1} \mathrm{~h}^{-1}$ at $14^{\circ} \mathrm{C}$ whilst that for mussels from Whitsand Bay was $2.6 \mathrm{I} \mathrm{g}^{-1} \mathrm{~h}^{-1}$. Relative retention efficiency of particles was generally similar for mussels from the 2 sites, declining to ca $28 \%$ for natural bacterioplankton of 0.513 to $0.524 \mu \mathrm{m}$ mean spherical diameter. These results suggest no significant intraspecific differences in filtration rates or relative particle retention efficiencies, for mussels from the 2 sites, in spite of major differences in particle concentrations at the sites. Although ca $65 \%$ of the natural bacterioplankton were cleared from the experimental vessels after $335 \mathrm{~min}$ at $14^{\circ} \mathrm{C}$, carbon and nitrogen yield from bacterioplankton at natural concentrations is likely to be small. The complete particle spectrum, represented by living phytoplankton cells, detritus and bacterioplankton, would need to be exploited by the Whitsand Bay population of mussels to sustain carbon and nitrogen demands since the total yield from all particulate size classes was only $713 \mu \mathrm{g} \mathrm{Ch}^{-1}$ and $78 \mu \mathrm{g} \mathrm{N} \mathrm{h}{ }^{-1}$ compared with an estimated minimum requirement of $737 \mu \mathrm{g} \mathrm{Ch}^{-1}$ and $45.5 \mu \mathrm{g} \mathrm{N} \mathrm{h}^{-1}$. The total carbon and nitrogen resource in the Lynher estuary was well in excess of the estimated requirements of the mussels. However, it is estimated that the free-living bacterial resource would contribute only $4.2 \%$ to the carbon budget and $17 \%$ to the nitrogen budget of the Lynher estuary mussels compared with 1.6 and $7 \%$ respectively of that of the open coast mussels. These results suggest that mussels from both the estuarine and coastal sites utilize phytoplankton or similar sized particles as a primary nutritional resource, although in other systems where bacterial standing stocks are high relative to other particulate resources, bacterioplankton may make a more important contribution to the carbon and nitrogen requirements of filter-feeding organisms.
\end{abstract}

\section{INTRODUCTION}

There have been numerous studies on the filtration rates and particle retention efficiency of marine bivalves (for reviews, see Jørgensen 1960, 1975a, Bayne 1976, Kiørboe \& Møhlenberg 1981). In general, particles $>3 \mu \mathrm{m}$ in diameter are efficiently retained, although in some bivalves such as Pecten sp. which lacks eulatero-frontal cilia, the filtration efficiency declines when the particle diameter is $<7 \mu \mathrm{m}$ and falls to only $20 \%$ at $1 \mu \mathrm{m}$ (Møhlenberg \& Riisgård 1978). Data for the mussel Mytilus edulis support these results for other bivalves, with a marked decline in filtration efficiency occurring in the presence of particles of $<2 \mu \mathrm{m}$ diameter (Vahl 1972). Jørgensen (1975b) found that the retention efficiency of particles of 1 to 2 $\mu \mathrm{m}$ diameter by $M$. edulis was below 30 to $70 \%$ of that for $6 \mu \mathrm{m}$ particles. 
Several studies have attempted to relate the abundance of different particulate size fractions to the consumption requirements of bivalves. Stuart \& Klumpp (1984) showed that the mussels Aulacomya ater, Choromytilus meridionalis and Perna perna* were each capable of retaining particles of 2 to $3 \mu \mathrm{m}$ with a high efficiency, but that the retention efficiency of 0.6 $\mu \mathrm{m}$ cells dropped to approximately $20 \%$. The $<1 \mu \mathrm{m}$ size fraction was estimated to be capable of meeting 5 to $21 \%$ of the carbon requirements of the bivalves, although other components of a kelp bed community, such as the sponges, were capable of meeting their entire carbon requirements by utilizing particles of $<1$ $\mu \mathrm{m}$ diameter.

More recently, Seiderer \& Newell (1985; see also Seiderer et al. 1984) have made some estimates of the significance of phytoplankton, plant detritus and bacteria as carbon and nitrogen resources during the upwelling-downwelling cycles which characterize kelp beds in the Southern Benguela upwelling system. Their results support those of Stuart \& Klumpp (1984) and show that particles in the bacterial size range are inefficiently retained by the kelp bed mussel Choromytilus meridionalis. Despite this, the standing stocks of free-living bacteria were comparable to the phytoplankton as a nitrogen resource during upwelling phases. These studies thus suggest that the bacterial resource is significant, but that it is probably exploited mainly by filter-feeders other than bivalves, especially in habitats where the phytoplankton biomass is high

There have, however, been some studies which show that bivalves which live in habitats where the bacterial biomass is high may be specifically adapted to exploit the bacterial size fraction. Wright et al. (1982) studied the clearance of natural bacterioplankton and phytoplankton by Mytilus edulis, the saltmarsh mussel Geukenisia demissa and the clam Mya arenaria. They showed that of the 3 , only $G$. demissa was capable of efficient clearance of bacteria, an adaptation which may allow the mussel to exploit the enhanced bacterial populations associated with saltmarshes (Palumbo \& Ferguson 1978). Again, Schleyer (1981) showed that there was a fall in the number of free-living coccoid bacteria as water flowed across a reef off the Natal coast of South Africa where the mussel Perna perna was abundant. Berry \& Schleyer (1983) subsequently showed that this mussel is able to retain particles down to $<0.46 \mu \mathrm{m}$ in diameter. This is roughly equivalent to the mean size of the free-living coccoid bacteria whose production was at least 4 times that of the phytoplankton in the water column of the study area.

\footnotetext{
- This species has subsequently been identified as Mytilus galloprovincialis by Grant \& Cherry (1985)
}

The following work was undertaken on 2 different populations of the mussel Mytilus edulis, one of which lives in the Lynher estuary and the other at an open coastal site at Whitsand Bay, Cornwall, UK, to determine the extent to which the filtration efficiency is related to the differing particle size spectra occurring in their natural habitats. Mussel populations are known to differ in their physiological responses to a variety of environmental factors (Bayne \& Widdows 1978, Widdows 1978, Bayne \& Worrall 1980, Widdows et al. 1984), but little is known of the food resource availability or whether there is an intraspecific adaptation by the estuarine population to exploit the elevated standing stocks of bacterioplankton which often characterize estuarine environments.

\section{MATERIALS AND METHODS}

Experimental procedure. Lynher mussel population. Specimens of the mussel Mytilus edulis L. were collected intertidally from Jupiter Point on the River Lynher estuary, Cornwall, UK, on 14 September 1984 just prior to the incoming tide reaching them, and were immediately transported to the laboratory where epiphytes and epifauna were removed. Ten mussels were then placed individually in 2.01 beakers containing 2.01 of $200 \mu \mathrm{m}$ filtered seawater which had been collected at the same time as the experimental mussels, and were held at $14^{\circ} \mathrm{C}$ in a constant temperature room. This was within the ambient daily temperature range recorded for the 2 sites at this time of the year, as Bayne \& Widdows (1978) also noted. Each vessel, including a control beaker containing $200 \mu \mathrm{m}$ filtered seawater, was gently aerated. Samples of 40 to $50 \mathrm{ml}$ were then removed for Coulter counting and $20 \mathrm{ml}$ for bacterial acridine orange direct counts (AODC) at time zero and after 30,60, 105, 140 and $335 \mathrm{~min}$. The shell length, breadth and dry tissue weight of each of the experimental mussels was recorded at the end of the experiment, and the results for each individual expressed per mg dry flesh weight. The mean shell length of the mussels was $4.821 \pm 0.188 \mathrm{~cm}$, shell breadth was $2.345 \pm 0.112 \mathrm{~cm}$, and dry flesh weight was $1.306 \pm 0.220 \mathrm{~g}$.

Whitsand mussel population. A similar series of experiments was carried out on mussels collected from an open coastal site at Whitsand Bay, Cornwall. Mussels and seawater were collected on 15 September 1984 from rocks at low tide and transported immediately to the laboratory, cleaned and placed in 21 vessels held at $14^{\circ} \mathrm{C}$ as before. Samples of 40 to $50 \mathrm{ml}$ for Coulter counting and $20 \mathrm{mI}$ for bacterial counts (AODC) were then taken from the control vessel and from each of the 10 experimental vessels containing 
mussels at time zero and for up to $135 \mathrm{~min}$. The mean shell length of the 10 mussels was $4.286 \pm 0.150 \mathrm{~cm}$, shell breadth was $1.943 \pm 0.260 \mathrm{~cm}$ and mean dry flesh weight was $0.471 \pm 0.104 \mathrm{~g}$.

Seawater sampling. Water samples were taken hourly by diving over the mussel bed in the Lynher estuary during a $12 \mathrm{~h}$ tidal cycle on 11 September 1984, starting at $0700 \mathrm{~h}$ when the water was high. Subsamples of $20 \mathrm{ml}$ were then placed in autoclaved scintillation vials with $1 \mathrm{ml} 25 \%$ glutaraldehyde for bacterial counts. Further subsamples were transported to the laboratory for Coulter counting, and $200 \mathrm{ml}$ was filtered on site through $25 \mathrm{~mm} \mathrm{GF/F} \mathrm{Whatman} \mathrm{filters} \mathrm{for}$ CHN analysis.

Particle counts. Particle counts in the seawater at the start of the experiment, and for up to $335 \mathrm{~min}$, were made with a Coulter Counter (Model TA II) equipped with 2 aperture tubes ( 70 and $280 \mu \mathrm{m}$ ) and a population accessory, interfaced with an Apple IIe micro-computer. The Coulter Counter was active from 1.58 to $102 \mu \mathrm{m}$ particle size diameters with overlap between the 2 aperture tubes at $12.7 \mu \mathrm{m}$ particle diameter. Bacterial sized particles were therefore excluded from the Coulter counts. Bacteria were counted by the AODC technique of Hobbie et al. (1977) and were classified into 7 morphs (Painting et al. 1985) whose dimensions and relative abundance yielded a weighted mean spherical diameter for the population. Both the Coulter and AODC counts were corrected for the control counts. The biomass was then calculated from the weighted mean cell volume using a specific gravity of $1.1 \mathrm{~g} \mathrm{~cm}^{-3}$ (Luria 1960, Doetsch \& Cook 1973; see also Linley et al. 1981) and a dry: wet ratio of 0.2 (Luria $1960)$. The carbon equivalent was then calculated as $50 \%$ of the dry biomass (Luria 1960, Doetsch \& Cook 1973), and the result converted to the nitrogen equivalent using a bacterial $\mathrm{C} / \mathrm{N}$ ratio of 4.0 .

CHN analysis. Samples of $200 \mathrm{ml}$ seawater were filtered through $25 \mathrm{~mm}$ Whatman $\mathrm{GF} / \mathrm{F}$ filters which had been previously ashed at $450^{\circ} \mathrm{C}$ for $6 \mathrm{~h}$. The filters from samples which had been filtered in the field were stored on ice and then oven-dried at $50^{\circ} \mathrm{C}$ for $12 \mathrm{~h}$ before being analysed with a Heraeus elemental analyser using cyclohexanone $(10.14 \% \mathrm{~N} ; 51.79 \% \mathrm{C})$ as a standard (Monar 1972).

Estimation of clearance rate. The clearance of particles in each of the size fractions, including bacteria, was estimated following the method of Coughlan (1969):

Clearance rate, $m=\frac{M}{n \cdot t} \cdot \log _{e} \frac{\text { Conc. } t_{1}}{\text { Conc. } t_{2}}$

where $\mathrm{m}=$ filtration rate $\left(\mathrm{l} \mathrm{h}^{-1}\right) ; \mathrm{M}=$ volume of suspension (1); Conc. $t_{1}=$ concentration at time $t_{1}$; Conc. $t_{2}=$ concentration at a subsequent time $t_{2}$; and $n$ $=$ number of individuals (i.e. 1 in this case).
At the natural food concentration used, there was no visible production of faeces or pseudofaeces. Resuspension of bioseston as reported by Hildreth (1980) was thus unlikely to have introduced an error into the estimates over the time course of our experiments. Estimates were made of the clearance rate from time zero to $30 \mathrm{~min}$, from 30 to $60 \mathrm{~min}$ and from 60 to 105 min in each particle channel and for each of the 10 experimental mussels. Simultaneous estimates of the clearance rate in each particle size thus avoided some of the problems associated with the measurement of clearance rate from mixed particle size spectra, and allowed us to calculate the relative significance of each particle size fraction independently (Williams 1982). The rates of particle clearance were then corrected for the control values, and calculated per mg dry tissue of each experimental mussel. These values $\left.\left(1 \mathrm{~h}^{-1} \text { [mg dry flesh }\right]^{-1}\right)$ were then expressed as the rate for a $1 \mathrm{~g}$ dry tissue weight mussel using a weight exponent of 0.34 (Bayne \& Widdows 1978).

\section{RESULTS}

\section{Resource availability}

The particulate resources in the water column at the Jupiter Point site on the Lynher estuary and at the open coastal site at Whitsand Bay, Cornwall, were assessed in terms of bacterial numbers, particle concentration and the equivalent carbon and nitrogen. The carbon and nitrogen in the particulate fraction between 1.58 and $40.3 \mu \mathrm{m}$ diameter was calculated from the CHN analysis of the total particulate fraction and the relative volume of particles in each channel, assuming that the $\mathrm{C} / \mathrm{N}$ ratio is independent of particle size.

The relative proportions of bacterial morphs, their mean spherical diameter and the weighted mean diameter of the populations in seawater from Jupiter Point and Whitsand Bay are shown in Table 1. From this, the weighted mean diameter of the Lynher estuary bacteria was estimated to be $0.524 \mu \mathrm{m}$ and that of the Whitsand Bay bacteria to be $0.513 \mu \mathrm{m}$. There were few obvious differences in size or composition of the free-living bacterial communities from each site, the most common components being small cocci of $0.25 \mu \mathrm{m}$, large cocci of $0.56 \mu \mathrm{m}$ and small rods of $0.725 \mu \mathrm{m}$ mean spherical diameter. These together comprised $87 \%$ of the free-living bacterial population at Whitsand Bay and $86 \%$ of that in the waters of the Lynher estuary.

Table 2 shows the bacterial numbers and the carbon and nitrogen in the particulate matter filtered from $200 \mathrm{ml}$ samples through a Whatman GF/F filter at hourly intervals during a tidal cycle at Jupiter Point. 
Table 1. Relative proportion of bacterial morphs, their mean spherical diameter and the weighted mean diameter of the bacterioplankton in seawater samples collected on 14 Sep 1984 from Jupiter Point on the Lynher estuary, Cornwall, and on 15 Sep 1984 from an open coastal site at Whitsand Bay, Cornwall, UK. The weighted mean spherical diameter of the Whitsand Bay population was $0.513 \mu \mathrm{m}$ and that of the Lynher estuary population was $0.524 \mu \mathrm{m}$

\begin{tabular}{|c|c|c|c|c|c|}
\hline \multirow[t]{2}{*}{ Morphotype } & \multirow[b]{2}{*}{$\begin{array}{c}\text { Mean spherical } \\
\text { diameter }(\mu \mathrm{m})\end{array}$} & \multicolumn{2}{|c|}{ Whitsand Bay } & \multicolumn{2}{|c|}{ Lynher estuary } \\
\hline & & $\begin{array}{l}\text { Mean numerical } \\
\text { composition }(\%)\end{array}$ & $\begin{array}{l}\text { Weighted mean } \\
\text { diameter }(\mu \mathrm{m})\end{array}$ & $\begin{array}{l}\text { Mean numerical } \\
\text { composition }(\%)\end{array}$ & $\begin{array}{l}\text { Weighted mean } \\
\text { diameter }(\mu \mathrm{m})\end{array}$ \\
\hline Small cocci & 0.25 & $36.77 \pm 7.96$ & 0.092 & $32.08 \pm 3.53$ & 0.080 \\
\hline Large cocci & 0.56 & $25.85 \pm 2.62$ & 0.145 & $29.35 \pm 3.16$ & 0.164 \\
\hline Small rods & 0.725 & $24.94 \pm 6.19$ & 0.181 & $24.78 \pm 3.39$ & 0.179 \\
\hline Large rods & 1.15 & $1.10 \pm 0.85$ & 0.013 & $0.15 \pm 0.32$ & 0.002 \\
\hline Small U-shaped & 0.725 & $10.29 \pm 3.93$ & 0.075 & $13.39 \pm 2.65$ & 0.097 \\
\hline Large U-shaped & 1.15 & - & - & - & - \\
\hline S-shaped & 0.725 & $0.94 \pm 0.72$ & 0.007 & $0.24 \pm 0.28$ & 0.002 \\
\hline Entire population & & & 0.513 & & 0.524 \\
\hline
\end{tabular}

The sampling site was exposed for a total of $4 \mathrm{~h}$ per tidal cycle, so a series of 4 samples was taken on the ebbing tide by diving over the mussel population, and a further set of 4 was taken on the flood tide.

Carbon and nitrogen in the particulate fraction varied somewhat over the tidal cycle, yielding values of 605 to $620 \mu \mathrm{g} \mathrm{Cl}^{-1}$ and 60 to $80 \mu \mathrm{g} \mathrm{N}{ }^{-1}$ at high water.

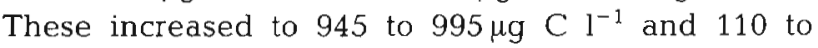
$145 \mu \mathrm{g} \mathrm{N}{ }^{-1}$ as the tide ebbed. The mean particulate carbon resource in the water column, excluding freeliving bacteria, available for exploitation by the mussels was thus $781.9 \pm 147.2 \mu \mathrm{g} \mathrm{l^{-1 }}$ with a corresponding nitrogen value of $97.4 \pm 25.4 \mu \mathrm{g} 1^{-1}$. The estimates of POM load agree with those obtained by Bayne \& Widdows (1978) for the Lynher estuary. Bacterial numbers, however, showed only a small variation over the tidal cycle, ranging from $2.04 \times 10^{6}$ to
$3.43 \times 10^{6}$ cells $\mathrm{ml}^{-1}$ and with a mean concentration of $2.75 \pm 0.43 \times 10^{6}$ cells $\mathrm{ml}^{-1}$.

The bacterial numbers in seawater collected from the sampling site at low tide and used at time zero in the filtration experiments are summarized in Table 3. They were $2.99 \pm 0.274 \times 10^{6}$ cells $\mathrm{ml}^{-1}$, yielding a wet biomass of $416.4 \pm 104.2 \mu \mathrm{g} \mathrm{l}^{-1}$. The carbon equivalent was thus $41.64 \pm 10.42 \mu \mathrm{gl}^{-1}$ (i.e. $\times 0.1$ ) and the nitrogen $10.41 \pm 2.61 \mu \mathrm{g} \mathrm{l}^{-1}$ at a $\mathrm{C} / \mathrm{N}$ of 4.0 . The numbers of particles in the size range 1.58 to $40.0 \mu \mathrm{m}$ diameter in the Lynher estuary water used in the feeding experiments are also shown in Table 3 . The particulate load in the water column of the Lynher estuary is evidently high, with maximum carbon in the $8.0 \mu \mathrm{m}$ diameter fraction. The total resource amounted to $839.9 \mu \mathrm{g} \mathrm{C} 1^{-1}$ and $107.7 \mu \mathrm{g} \mathrm{Nl} \mathrm{N}^{-1}$. Of this, bacteria represented only $5 \%$ of the carbon and $9.7 \%$ of the

Table 2. Bacterial numbers and carbon and nitrogen in the particulate fraction retained on Whatman GF/F filters at hourly intervals during a tidal cycle at Jupiter Point on the Lynher estuary, Cornwall, UK, on 11 Sep 1984. The intertidal site was exposed for $4 \mathrm{~h}$ during the tidal cycle. Bacterial numbers and CHN data for water from the coastal site at Whitsand are also given

\begin{tabular}{|c|c|c|c|c|}
\hline $\begin{array}{c}\text { Time after High Water } \\
\text { (h) }\end{array}$ & $\begin{array}{l}\text { Bacterial numbers } \\
\text { (cells } \mathrm{ml}^{-1} \times 10^{6} \text { ) }\end{array}$ & $\begin{array}{l}\text { Total carbon } \\
\qquad\left(\mu g 1^{-1}\right)\end{array}$ & $\begin{array}{l}\text { Total nitrogen } \\
\qquad\left(\mu \mathrm{g} \mathrm{l}^{-1}\right)\end{array}$ & $\mathrm{C} / \mathrm{N}$ ratio \\
\hline \multicolumn{5}{|l|}{ Lynher resource } \\
\hline 1 & 2.04 & 605 & 80 & 7.56 \\
\hline 2 & 2.79 & 735 & 100 & 7.35 \\
\hline 3 & 2.86 & 810 & 100 & 8.10 \\
\hline 4 & 3.01 & 945 & 110 & 8.59 \\
\hline Site exposed & - & - & - & - \\
\hline 9 & 3.43 & 995 & 145 & 6.86 \\
\hline 10 & 2.96 & 870 & 105 & 8.29 \\
\hline 11 & 2.59 & 675 & 80 & 8.44 \\
\hline 12 & 2.31 & 620 & 60 & 10.33 \\
\hline Mean & $2.75 \pm 0.43$ & $781.9 \pm 147.2$ & $97.5 \pm 25.4$ & 8.02 \\
\hline Whitsand resource & $1.38 \pm 0.16$ & $344.7 \pm 15.9$ & $35.3 \pm 2.5$ & 9.76 \\
\hline
\end{tabular}


Table 3. Mytilus edulis. Clearance rate $\left(\mathrm{l} \mathrm{h}^{-1} \mathrm{~g}^{-1}\right)$ and particle retention efficiency (\%) between 30 and 60 min for mussels collected from Jupiter Point on the Lynher estuary, Cornwall, UK, on 14 Sep 1984. Results for retention efficiency have been expressed as a percentage of the retention of particles of $16.0 \mu \mathrm{m}$ diameter, assuming the latter to be retained with $100 \%$ efficiency. Resource availability in the natural water used in the experiments at time zero is shown as particle concentration (no. $\left.\mathrm{ml}^{-1}\right)$ and as carbon and nitrogen $\left(\mu \mathrm{gl}^{-1}\right)$. These have been calculated for the bacteria using a $\mathrm{C} / \mathrm{N}$ of 4.0 . The carbon and nitrogen in the other particles is calculated from the $\mathrm{CHN}$ of the particulate fraction $(\mathrm{C} / \mathrm{N}=8.02$; Table 2$)$ and the relative percentage volume of particles in each channel, assuming that $\mathrm{C} / \mathrm{N}$ is independant of particle size. Yield has been calculated from the clearance rate of $2.604 \mathrm{l} \mathrm{h}^{-1}$ at $100 \%$ efficiency, the retention efficiency and the resource avilability in each size fraction. Results are expressed for a $1 \mathrm{~g}$ dry tissue weight mussel and have been corrected for control values

\begin{tabular}{|c|c|c|c|c|c|c|c|c|c|c|c|}
\hline \multicolumn{12}{|c|}{ Lynher mussel population } \\
\hline \multirow{3}{*}{$\begin{array}{c}\text { Particle } \\
\text { diameter } \\
\text { ( } \mu \mathrm{m})\end{array}$} & \multirow{3}{*}{$\begin{array}{c}\text { Clearance } \\
\text { rate } \\
\left(1 \mathrm{~h}^{-1} \mathrm{~g}^{-1}\right)\end{array}$} & \multirow[b]{3}{*}{ SD } & \multirow{3}{*}{\multicolumn{2}{|c|}{$\begin{array}{r}\text { Retention } \\
\text { efficiency } \\
N \quad(\%)\end{array}$}} & \multicolumn{3}{|c|}{ Resource availability } & \multicolumn{4}{|c|}{ Yield } \\
\hline & & & & & $\begin{array}{c}\text { Particle concen- } \\
\text { tration }\end{array}$ & Carbon & Nitrogen & Carb & & Nitrog & \\
\hline & & & & & (no. $\mathrm{ml}^{-1}$ ) & $\left(\mu \mathrm{g} \mathrm{l}^{-1}\right)$ & $\left(\mu g 1^{-1}\right)$ & $\left(\mu \mathrm{g} \mathrm{h}^{-1}\right)$ & $(\%)$ & $\left(\mu g h^{-1}\right)$ & $(\%)$ \\
\hline \multicolumn{12}{|l|}{ Bacteria } \\
\hline$(0.524)$ & 0.7391 & 0.751 & 4 & 28.4 & $2.99 \pm 0.274 \times 10^{6}$ & $41.64 \pm 10.42$ & $10.41 \pm 2.61$ & 30.79 & 1.52 & 7.70 & 3.07 \\
\hline 1.580 & 1.4852 & 0.234 & 7 & 57.0 & $55.9 \times 10^{3}$ & 14.86 & 1.85 & 22.05 & 1.09 & 2.75 & 1.09 \\
\hline 2.00 & 2.1448 & 0.316 & 7 & 82.4 & $31.5 \times 10^{3}$ & 17.20 & 2.15 & 36.90 & 1.82 & 4.61 & 1.84 \\
\hline 2.52 & 2.3222 & 0.369 & 7 & 89.2 & $27.4 \times 10^{3}$ & 29.71 & 3.71 & 69.00 & 3.40 & 8.62 & 3.43 \\
\hline 3.18 & 2.5278 & 0.432 & 7 & 97.1 & $20.0 \times 10^{3}$ & 43.79 & 5.46 & 110.71 & 5.46 & 13.80 & 5.50 \\
\hline 4.00 & 2.6210 & 0.573 & 7 & 100.0 & $12.9 \times 10^{3}$ & 56.30 & 7.02 & 146.60 & 7.23 & 18.28 & 7.28 \\
\hline 5.04 & 2.6303 & 0.509 & 7 & 100.0 & 8142 & 71.15 & 8.87 & 185.24 & 9.13 & 23.09 & 9.20 \\
\hline 6.34 & 2.5090 & 0.408 & 7 & 96.4 & 5234 & 91.48 & 11.41 & 229.60 & 11.31 & 28.64 & 11.41 \\
\hline 8.00 & 2.5281 & 0.493 & 7 & 97.1 & 2750 & 96.17 & 11.99 & 243.13 & 11.98 & 30.31 & 12.07 \\
\hline 10.1 & 2.3242 & 0.542 & 7 & 89.3 & 1131 & 78.97 & 9.85 & 183.61 & 9.05 & 22.90 & 9.12 \\
\hline 12.7 & 2.5221 & 0.731 & 7 & 96.9 & 585 & 82.10 & 10.24 & 207.13 & 10.21 & 25.83 & 10.29 \\
\hline 16.0 & 2.6036 & 1.124 & 7 & 100.0 & 246 & 69.59 & 8.68 & 181.18 & 8.93 & 22.60 & 9.00 \\
\hline 20.2 & 2.3461 & 1.204 & 7 & - & 95 & 53.17 & 6.63 & 138.43 & 6.82 & 17.26 & 6.87 \\
\hline 25.4 & 2.1444 & 1.197 & 5 & - & 31 & 53.19 & 4.39 & 138.48 & 6.83 & 11.43 & 4.55 \\
\hline 32.0 & 2.5822 & 0.137 & 2 & - & 10 & 22.68 & 2.83 & 59.05 & 2.91 & 7.37 & 2.94 \\
\hline \multirow[t]{2}{*}{40.0} & - & - & 0 & - & 4 & 17.98 & 2.24 & 46.81 & 2.31 & 5.83 & 2.32 \\
\hline & & & & & & $\Sigma=839.98$ & $\Sigma=107.73$ & $\Sigma=2028.71$ & & $\Sigma=251.02$ & \\
\hline
\end{tabular}

nitrogen potentially available for exploitation as a food resource in the water column.

The corresponding values for the particulate fraction collected from the open coastal site at Whitsand Bay, Cornwall, and subsequently used in the filtration experiments are shown in Table 4 . The particulate fraction, excluding free-living bacteria, had maximum carbon in the 12.7 to $16.0 \mu \mathrm{m}$ range and a measured (CHN analysis) concentration of $344.67 \pm 15.88 \mu \mathrm{g} \mathrm{C}$ $\mathrm{I}^{-1}$ and $35.33 \pm 2.52 \mu \mathrm{g} \mathrm{N} \mathrm{l^{-1 }}$ with a $\mathrm{C} / \mathrm{N}$ of 10.25 (see Table 2). The free-living bacterial numbers were 1.38 $\pm 0.157 \times 10^{6}$ cells $\mathrm{ml}^{-1}$, yielding a wet biomass of $165.0 \pm 34.3 \mu \mathrm{g} \mathrm{l}^{-1}$. The bacterial carbon resource thus comprised $16.5 \pm 3.43 \mu \mathrm{g} \mathrm{l}^{-1}$ and $4.13 \pm 0.86 \mu \mathrm{g} \mathrm{N} \mathrm{N}^{-1}$ assuming a $\mathrm{C} / \mathrm{N}$ of 4.0 . The total resource potentially available at the open coastal site was thus considerably lower than in the estuary (ca $40 \%$ ), amounting to $331.3 \mu \mathrm{g} \mathrm{C} 1^{-1}$ and $36.41 \mu \mathrm{g} \mathrm{N} 1^{-1}$. Of this, free-living bacteria represented approximately $5 \%$ of the carbon and $11.3 \%$ of the nitrogen in the water column. It is important to note that despite the differences in total particle load between the 2 sites, bacteria represented approximately $5 \%$ of the carbon for each site. It is well known that bacterial densities are closely correlated to chlorophyll a concentrations (Lancelot \& Billen 1984) and also to POC concentration (Lucas 1986). Except in special circumstances (e.g. upwelling areas, Seiderer \& Newell 1985) bacterial carbon is always likely to be $<10 \%$ of the total carbon in surface waters. As most bacteria are free-living (Joint \& Morris 1982), exploitation of this resource requires a specific ability to remove particles within this size range. However, where bacteria are attached to larger suspended particles they may become available to other consumers and furthermore, enrich the particle resource (Newell 1965).

\section{Filtration by mussels}

Clearance rates (at $14{ }^{\circ} \mathrm{C}$ ) for each of the 3 time intervals ( 0 to 30,30 to 60 and 60 to 105 mins) did not vary by more than approximately $20 \%$ for any particle size. Nevertheless the first ( 0 to $30 \mathrm{mins}$ ) and last (60 to 105 mins) intervals gave generally lower rates than the intermediate interval. For the initial period, lower rates were recorded because the mussels did not always open immediately and in the last period, low rates were associated with low particle concentrations 
Table 4. Mytilus edulis. Clearance rate $\left(\mathrm{h} \mathrm{h}^{-1} \mathrm{~g}^{-1}\right)$ and particle retention efficiency (\%) between 30 and 60 min for mussels collected from an open coastal site at Whitsand Bay, Cornwall on 15 Sep 1984. Results for retention efficiency have been expressed as a percentage of the retention of particles of $10.1 \mu \mathrm{m}$ diameter, assuming the latter to be retained with $100 \%$ efficiency. Resource availability in the natural water used in the experiments at time zero is shown as particle concentration (no. $\left.\mathrm{ml}^{-1}\right)$ and as carbon and nitrogen $\left(\mu \mathrm{g} \mathrm{l}^{-1}\right)$. These have been calculated for the bacteria using a $\mathrm{C} / \mathrm{N}$ of 4.0 . The carbon and nitrogen in the other particles is calculated from the $\mathrm{CHN}$ of the particulate fraction $(\mathrm{C} / \mathrm{N}=9.76$; Table 2$)$ and the relative percentage volume of particles in each channel, assuming that $\mathrm{C} / \mathrm{N}$ is independent of particle size. Yield has been calculated from the clearance rate of $2.56 \mathrm{I} \mathrm{h}^{-1}$ at $100 \%$ efficiency, the retention efficiency and the resource availability in each size fraction.

Results are expressed for a $1 \mathrm{~g}$ dry tissue weight mussel and have been corrected for control values

\begin{tabular}{|c|c|c|c|c|c|c|c|c|c|c|c|}
\hline \multicolumn{12}{|c|}{ Whitsand mussel population } \\
\hline \multirow{3}{*}{$\begin{array}{c}\text { Particle } \\
\text { diameter } \\
(\mu \mathrm{m})\end{array}$} & \multirow{3}{*}{$\begin{array}{c}\text { Clearance } \\
\text { rate } \\
\left(1 \mathrm{~h}^{-1} \mathrm{~g}^{-1}\right)\end{array}$} & \multirow[b]{3}{*}{ SD } & \multirow{3}{*}{\multicolumn{2}{|c|}{$\begin{array}{l}\text { Retention } \\
\text { efficiency } \\
N \quad(\%)\end{array}$}} & \multicolumn{3}{|c|}{ Resource availability } & \multicolumn{4}{|c|}{ Yield } \\
\hline & & & & & $\begin{array}{c}\text { Particle concen- } \\
\text { tration }\end{array}$ & Carbon & Nitrogen & Carbo & & Nitro & \\
\hline & & & & & $\left(\right.$ no. $\left.\mathrm{ml}^{-1}\right)$ & $\left(\mu g l^{-1}\right)$ & $\left(\mu \mathrm{g} \mathrm{l}^{-1}\right)$ & $\left(\mu g \mathrm{~h}^{-1}\right)$ & $(\%)$ & $\left(\mu g \mathrm{~h}^{-1}\right)$ & $(\%)$ \\
\hline \multicolumn{12}{|l|}{ Bacteria } \\
\hline$(0.513)$ & & $\begin{array}{l}0.8479 \\
0.5050\end{array}$ & $\begin{array}{l}9 \\
9\end{array}$ & $\begin{array}{l}28.6 \\
22.6\end{array}$ & $\begin{array}{c}13.8 \pm 0.157 \times 10^{6} \\
47.9 \times 10^{3}\end{array}$ & $\begin{array}{c}16.50 \pm 3.43 \\
7.20\end{array}$ & $\begin{array}{c}4.13 \pm 0.86 \\
0.74\end{array}$ & $\begin{array}{r}12.08 \\
4.16\end{array}$ & $\begin{array}{l}1.69 \\
0.58\end{array}$ & $\begin{array}{l}3.02 \\
0.43\end{array}$ & $\begin{array}{l}3.88 \\
0.55\end{array}$ \\
\hline 1.58 & $\begin{array}{l}0.5776 \\
1.2249\end{array}$ & 0.4307 & 9 & $\begin{array}{l}22.0 \\
47.9\end{array}$ & $2.56 \times 10^{3}$ & 7.76 & 0.79 & 9.51 & 1.33 & 0.96 & $\begin{array}{l}0.55 \\
1.23\end{array}$ \\
\hline 2.00 & & & & & & & & & & & \\
\hline 2.52 & 1.4628 & 0.3959 & 9 & 57.1 & $18.9 \times 10^{3}$ & 11.47 & 1.18 & 16.78 & 2.35 & 1.72 & 2.20 \\
\hline 3.18 & 1.6585 & 0.4446 & 9 & 64.8 & $11.4 \times 10^{3}$ & 13.89 & 1.42 & 23.04 & 3.23 & 2.35 & 3.02 \\
\hline 4.00 & 1.7743 & 0.5335 & 9 & 69.3 & 6677 & 16.17 & 1.66 & 28.68 & 4.02 & 2.94 & 3.78 \\
\hline 5.04 & 1.9121 & 0.5973 & 9 & 74.7 & 3918 & 19.13 & 1.96 & 36.57 & 5.13 & 3.75 & 4.82 \\
\hline 6.34 & 1.9155 & 0.4870 & 9 & 74.8 & 2373 & 22.99 & 2.36 & 44.01 & 6.18 & 4.52 & 5.81 \\
\hline 8.00 & 1.9386 & 0.6918 & 9 & 75.7 & 1277 & 24.75 & 2.54 & 47.82 & 6.71 & 4.92 & 6.32 \\
\hline 10.1 & 2.5594 & 0.8065 & 9 & 100.0 & 634 & 24.57 & 2.52 & 62.88 & 8.82 & 6.45 & 8.29 \\
\hline 12.7 & 1.8375 & 0.4446 & 8 & - & 434 & 33.61 & 3.44 & 86.02 & 12.07 & 8.80 & 11.30 \\
\hline 16.0 & 2.2437 & 0.4424 & 7 & - & 220 & 34.23 & 3.51 & 87.61 & 12.29 & 8.98 & 11.54 \\
\hline 20.2 & 2.5664 & 0.6679 & 7 & - & 99 & 30.71 & 3.15 & 78.60 & 11.03 & 8.06 & 10.35 \\
\hline 25.4 & 3.1482 & 0.9034 & 5 & - & 42 & 26.06 & 2.67 & 66.70 & 9.36 & 6.83 & 8.77 \\
\hline 32.0 & 5.5592 & 2.1073 & 5 & - & 18 & 22.40 & 2.30 & 57.33 & 8.04 & 5.89 & 7.57 \\
\hline \multirow[t]{2}{*}{40.3} & 5.2085 & 2.0618 & 4 & - & 8 & 19.85 & 2.04 & 50.80 & 7.13 & 5.22 & 6.71 \\
\hline & & & & & & $\Sigma=331.3$ & $\Sigma=36.41$ & $\Sigma=712.59$ & & $\Sigma=77.84$ & \\
\hline
\end{tabular}

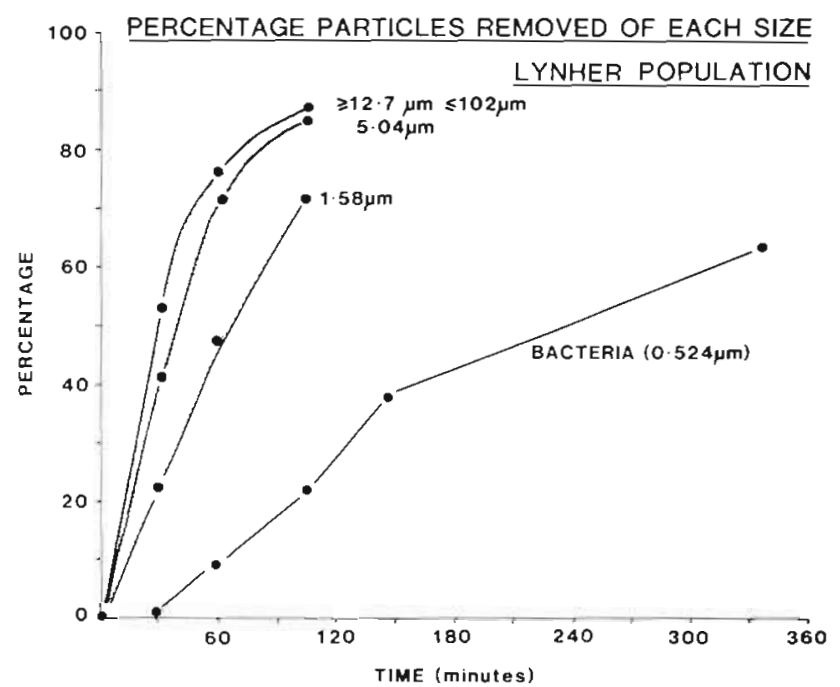

Fig. 1. Mytilus edulis. Graphs showing the percentage removal of particles of $>12.7<102 \mu \mathrm{m}, 5.04 \mu \mathrm{m}, 1.58 \mu \mathrm{m}$ and bacteria of $0.524 \mu \mathrm{m}$ weighted mean cell diameter by mussels collected from the Lynher estuary, Cornwall and held in 21 seawater at $14{ }^{\circ} \mathrm{C}$. Note that removal of bacterial cells reaches approximately $65 \%$ after $335 \mathrm{~min}$. Data have been corrected for control values

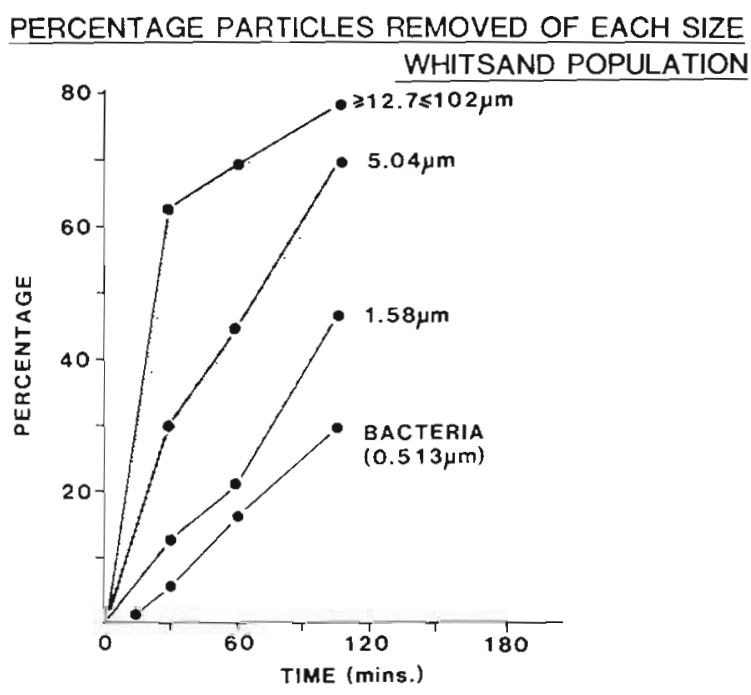

Fig. 2. Mytilus edulis. Graphs showing the percentage removal of particles of $>12.7<102 \mu \mathrm{m}, 5.04 \mu \mathrm{m}, 1.58 \mu \mathrm{m}$ and bacteria of $0.513 \mu \mathrm{m}$ weighted mean cell diameter by mussels collected from an open coastal site at Whitsand Bay, Cornwall and held in $2 \mathrm{l}$ seawater at $14^{\circ} \mathrm{C}$. Data have been corrected for control values 
when as much as $75 \%$ of the particles had been removed (see Fig. 1 \& 2). Clearance rates given are therefore calculated for the interval 30 to $60 \mathrm{~min}$. Rates were then expressed as 1 [g dry tissue $]^{-1} \mathrm{~h}^{-1}$ corrected for a $1.0 \mathrm{~g}$ mussel using a weight exponent of 0.34 after Bayne \& Widdows (1978).

The results for mussels collected from the Lynher estuary are summarized in Table 3. Also shown is the relative retention efficiency of particles in each size class. Because of increased vanability and error in calculating clearance rates from channels containing small numbers of large particles, the results have been expressed as a percentage of the retention of particles of $16.0 \mu \mathrm{m}$ diameter, and it has been assumed that all particles larger than this are retained with $100 \%$ efficiency. It is apparent from Table 3 that the weightspecific clearance rate of particles $>16.0 \mu \mathrm{m}$ diameter by Mytilus edulis from the Lynher estuary site was approximately $2.5 \mathrm{l}[\mathrm{g} \text { dry tissue }]^{-1} \mathrm{~h}^{-1}$ at $14^{\circ} \mathrm{C}$. This result agrees with those reported elsewhere for $M$. edulis from the Lynher estuary (Bayne \& Widdows 1978).

It will also be noticed that the particle retention efficiency declined from a nominal $100 \%$ in the presence of particles $>16.0 \mu \mathrm{m}$ diameter to $82 \%$ in the $2.0 \mu \mathrm{m}$ size range. The retention efficiency then declined to $57 \%$ in the $1.58 \mu \mathrm{m}$ size range and was $28 \%$ in the presence of natural bacterioplankton of weighted mean spherical cell diameter $0.524 \mu \mathrm{m}$. These results conform with those reported for Mytilus edulis by Vahl (1972) and Jørgensen (1975b) who also found a reduction in retention efficiency when the particle diameter was $<1$ to $2 \mu \mathrm{m}$ (see also Stuart \& Klumpp 1984).

Similar data for mussels collected from the open shore at Whitsand Bay and measured in the presence of natural water from the site are summarized in Table 4. In this case, increased variability of the weight-specific clearance rates was encountered in the 12.7 to $40.3 \mu \mathrm{m}$ particle diameter range when fewer values of clearance rate could be calculated because the concentration at $t_{1}$ was often less than at $t_{2}$ (see Eqn 1). Values for the relative particle retention efficiency were therefore calculated for a nominal efficiency of $100 \%$ in the presence of particles of $10.1 \mu \mathrm{m}$ diameter. In this case, the weight-specific clearance rate declined from 2.6 to $1.22 \mathrm{l}$ [g dry tissue ${ }^{-1} \mathrm{~h}^{-1}$ in the $2.0 \mu \mathrm{m}$ particle size range, $0.58 \mathrm{I} \mathrm{g}^{-1} \mathrm{~h}^{-1}$ in the $1.58 \mu \mathrm{m}$ range and $0.731 \mathrm{~g} \mathrm{~g}^{-1}$ $\mathrm{h}^{-1}$ in the presence of natural bacterioplankton of weighted mean spherical cell diameter $0.513 \mu \mathrm{m}$.

Values for the weight-specific clearance rates of the mussel populations from the Lynher estuary and from the open coastal site at Whitsand Bay were generally similar over much of the size range of natural particulate material, from bacterioplankton up to particles of
$16.0 \mu \mathrm{m}$ diameter. At their maximum retention efficiencies, both mussel populations had very similar clearance rates of approximately $2.6 \mathrm{l} \mathrm{g}^{-1} \mathrm{~h}^{-1}$. Differences between the apparent rates in the presence of particles $>16.0 \mu \mathrm{m}$ diameter may be ascribed to the relatively smaller number of particles in this size range $\left(<250 \mathrm{ml}^{-1}\right)$, and the resultant errors introduced into our experimental determination of clearance rate.

The relative retention efficiency of the mussels collected from Whitsand Bay seems generally somewhat lower than that of the Lynher estuary mussels although the retention efficiency of natural bacterioplankton was very similar (approximately $28 \%$ ) for both populations. Table 4 shows that the retention efficiency for mussels from Whitsand Bay fell from a nominal $100 \%$ at $10.1 \mu \mathrm{m}$ particle diameter to $57.1 \%$ at $2.52 \mu \mathrm{m}$, $47.9 \%$ at $2.0 \mu \mathrm{m}, 22.6 \%$ at $1.58 \mu \mathrm{m}$ and was $28.6 \%$ in the presence of natural bacterioplankton of $0.513 \mu \mathrm{m}$ weighted mean spherical cell diameter.

These results suggest that there are no significant intraspecific differences between the filtration rates or relative particle retention efficiencies of mussels collected from the River Lynher estuary and from the open coastal site at Whitsand Bay, Cornwall, despite the major differences in quantities of particulate matter at the 2 sites. In both cases the retention efficiency reaches values of $>75 \%$ in the presence of particles $>8.0 \mu \mathrm{m}$ in diameter which dominate the resource in the 2 habitats. It should be noted however, that a retention efficiency of 23 to $29 \%$ can be achieved in the presence of natural concentrations of marine bacterioplankton of only 0.513 to $0.524 \mu \mathrm{m}$ diameter.

\section{Relative clearance of particulate matter}

The percentage clearance of particles of $>12.7$ to $<102 \mu \mathrm{m}, 5.04 \mu \mathrm{m}, 1.58 \mu \mathrm{m}$ and natural bacterioplankton from the water in the experimental vessels containing Mytilus edulis collected from the Lynher estuary is summarized in Fig. 1. Similar data for the mussels collected from the open coastal site at Whitsand Bay are shown in Fig. 2. As might be anticipated from the relation between clearance efficiency and particle size shown in Tables 3 \& 4, large particles are removed rapidly, 75 to $85 \%$ of those $>5.04 \mu \mathrm{m}$ diameter being removed in $90 \mathrm{~min}$. Smaller particles of $1.58 \mu \mathrm{m}$ are cleared at a slower rate, 40 to $60 \%$ being removed after 90 min incubation at $14{ }^{\circ} \mathrm{C}$. Finally, because of the lower relative retention efficiency of bacteria, only 20 to $25 \%$ of the natural marine bacterioplankton is removed from the flasks after $90 \mathrm{~min}$.

It is interesting to note, however, that uptake of bacteria can continue after particles $>1.58 \mu \mathrm{m}$ have been largely cleared from the medium. Fig. 2 shows 
that after $335 \mathrm{~min}$, as much as $65 \%$ of the natural marine bacterioplankton is removed from the seawater by the Lynher estuary mussels, even though the bacteria were of a small size and at the relatively low initial concentration of $2.99 \times 10^{6}$ cells $\mathrm{ml}^{-1}$. This suggests that although the natural resource is dominated by particles in the size range 4 to $20 \mu \mathrm{m}$, the mussels were also capable of exploiting free-living bacteria at concentrations which occur in the natural environment. Bacteria can become an important component of the available particulate material in upwelling systems and may then form a significant food resource for filter-feeding organisms (Seiderer et al. 1984, Stuart \& Klumpp 1984, Seiderer \& Newell 1985).

\section{Potential yield in relation to natural resource availability}

The particulate yield which is potentially available for exploitation by a $1 \mathrm{~g}$ mussel is given by the product of the irrigation rate $\left(V_{w}, \mathrm{lg}^{-1} \mathrm{~h}^{-1}\right.$; equivalent to the clearance rate at $100 \%$ retention efficiency), the particle retention efficiency and the natural resource availability in each particle size category.

These values are shown for the Lynher estuary population of Mytilus edulis in the final columns of Table 3 whilst those for the Whitsand Bay mussels are summarized in Table 4. From these data, it can be seen that of the total potential carbon yield of $2028.7 \mu \mathrm{g} \mathrm{h}^{-1}$ from particulate matter in the Lynher estuary, free-living bacteria represented only $1.52 \%$ whilst of the potential total nitrogen yield of $251.0 \mu \mathrm{g} \mathrm{h} \mathrm{h}^{-1}$, free-living bacteria would contribute only $3.07 \%$. Similarly, out of the total carbon yield of $712.6 \mu \mathrm{g} \mathrm{h}^{-1}$ available from filtration of the Whitsand Bay water, free-living bacteria represented only $1.69 \%$. Again, out of the total potential nitrogen yield of $77.8 \mu \mathrm{g} \mathrm{h} \mathrm{h}^{-1}$ from all size fractions, free-living bacteria would supply only $3.9 \%$, provided that all particulate fractions were equally digestible.

\section{DISCUSSION}

The results which have been summarized above show that the relative distribution of particles in the water column of the river Lynher estuary and at the open coastal site at Whitsand Bay is broadly similar, with maximum carbon and nitrogen in the 5 to $25 \mu \mathrm{m}$ diameter range. The carbon and nitrogen resource in the Lynher estuary is, however, approximately 3 times that in the water at Whitsand Bay, with the result that the relative significance of free-living bacteria as a carbon and nitrogen source is higher at the open sea site than in the estuarine waters.
Where the resource is dominated by particles in the larger size fractions, as occurs under natural conditions both in the Lynher estuary and under fully marine conditions at Whitsand Bay, the local mussels exploit large particles preferentially to free-living bacteria. The latter, however, represent an exploitable resource in the absence of larger particles, a $65 \%$ removal of natural marine bacterioplankton occurring in experimental vessels after $335 \mathrm{~min}$ at $14^{\circ} \mathrm{C}$ (Fig. 1). A similar uptake of bacterial suspensions by the clam Venus verrucosa has recently been described by Amouroux (1986)

The ability of bivalves to filter particles in the bacterial size range, and to remove bacterioplankton from natural seawater, is, however, of little ecological significance unless the bacterial resource could meet the carbon and nitrogen demands of the consumer. Some estimate of the significance of bacteria as a trophic resource can be obtained from the carbon and nitrogen requirements of mussels in relation to the yield obtained from filtration of natural bacterioplankton. Bayne \& Widdows (1978) give values for the oxygen consumption of the Lynher population of mussels as $550 \mu \mathrm{l} \mathrm{O}_{2} \mathrm{~g}^{-1} \mathrm{~h}^{-1}$ and an absorption efficiency of $40 \%$. The minimum carbon requirements for respiration are calculated using the following equation:

$\mathrm{O}_{2}$ consumption $\left(\mu \mathrm{l} \mathrm{O}_{2} \mathrm{~g}^{-1} \mathrm{~h}^{-1}\right) \times \frac{12 \mu \mathrm{g} \mathrm{C}}{22.4 \mu \mathrm{O} \mathrm{O}_{2}} \times$ absorp-

tion efficiency $(\%)=$ carbon requirements for respiration $\left(\mu \mathrm{g} \mathrm{C} \mathrm{g}{ }^{-1} \mathrm{~h}^{-1}\right)$,

where $22.4 \mu \mathrm{l} \mathrm{O} \mathrm{O}_{2}=12 \mu \mathrm{gC}$.

Thus carbon requirements are:

$$
550 \times \frac{12}{22.4} \times \frac{100}{40}=736.5 \mu \mathrm{g} \mathrm{C} \mathrm{g}^{-1} \mathrm{~h}^{-1}
$$

Inspection of Tables $3 \& 4$ shows that the total carbon resource in the Lynher estuary is more than double this, reflecting a high particulate load and suggesting that there is considerable scope for growth and gametogenesis. Exploitation of the entire particle spectrum which is probably completed by living phytoplankton cells would, however, be barely adequate for the Whitsand Bay population to achieve a positive scope for growth, since the total carbon yield from all size classes was only $712.6 \mu \mathrm{g} \mathrm{h}^{-1}$. The carbon yield from the free-living bacterial resource would make a contribution of only ca $1.6 \%$ to the carbon budget of the open coast population of mussels and $4.2 \%$ of the budget for Lynher mussels.

In much the same way, the resource availability in relation to minimum nitrogen demand can be estimated from the excretion values of 15 to $25 \mu \mathrm{g} \mathrm{N} \mathrm{g}^{-1} \mathrm{~h}^{-1}$ 
and the protein absorption efficiency of $33 \%$ abtained by Bayne \& Widdows (1978) for Mytilus edulis. The minimum nitrogen requirements would thus be $45.5 \mu \mathrm{g}$ $\mathrm{g}^{-1} \mathrm{~h}^{-1}$, a value which could be met by utilisation of the complete resource available at the open coastal site. Particulate nitrogen resources considerably exceed nitrogen requirements by estuarine mussels. Free-living bacteria alone could meet only $7 \%$ of the nitrogen requirements of the mussels from the open coastal site, but as much as $17 \%$ of those from the Lynher estuary. Because of the high density of bacteria in the Lynher estuary, they may be more important as a nitrogen source than particles up to about $2.5 \mu \mathrm{m}$ in diameter which would include smaller Protozoa.

Natural marine bacterioplankton at the concentrations which we recorded in the water column in September 1984 thus appear to make an insignificant contribution to the carbon and nitrogen requirements of mussels from either the estuarine site on the river Lynher estuary or on the open coastal site at Whitsand Bay, Cornwall. In both cases the maximal yield is obtained from particles in the size range 5.0 to $25.0 \mu \mathrm{m}$, the full range of suspended particles being required to meet the estimated carbon and nitrogen requirements of mussels on the open coastal site.

These results support those from upwelling areas where mussels have been shown to exploit phytoplankton rather than free-living bacteria as a primary nutritional resource (Stuart \& Klumpp 1984, Seiderer \& Newell 1985). In other systems, however, and during periods of upwelling when phytoplankton is scarce, bacterial abundances may considerably exceed those recorded in the study (Wright et al. 1982, Berry \& Schleyer 1983, Seiderer \& Newell 1985). In the Southern Benguela upwelling system, for example, bacterial numbers may reach $6.0 \times 10^{6}$ cells $\mathrm{ml}^{-1}$, the mean carbon and nitrogen resource ranging from 58 to $82 \mu \mathrm{g}$ $\mathrm{C}^{-1}$ and 16 to $24 \mu \mathrm{g} \mathrm{N}^{-1}$ (Seiderer \& Newell 1985). Under these conditions, and in the absence of sufficient phytoplankton to meet consumer demands, the bacterioplankton may make a more important contribution to the carbon and particularly nitrogen requirements of macrofaunal filter-feeding organisms than that recorded in this study.

Acknowledgements. We thank Mr. Ian Humphrey for counting the bacterial samples, and Mrs Sandy Tolosana for typing the manuscript, both of the University of Cape Town. Both M. I. Lucas and J. L. Seiderer acknowledge travel support provided by UCT and the SANCOR Benguela Ecology Programme. The Maine Department of Marine Resources (USA) is acknowledged by S. E. Shumway; R. C. Newell is in receipt of a Royal Society Research Fellowship (London). We are grateful for the provision of research facilities at the Institute for Marine Environmental Research, Plymouth, and for the helpful comments on the manuscript by Dr. B. L. Bayne.

\section{LITERATURE CITED}

Amouroux, J. M. (1986). Comparative study of the carbon cycle in Venus verrucosa fed on bacteria and phytoplankton. Mar. Biol. 90: 237-241

Bayne, B. L. (ed.) (1976). Marine mussels. Cambridge Univ. Press, Cambridge

Bayne, B. L., Widdows, J. (1978). The physiological ecology of two populations of Mytilus edulis L. Oecologia (Berl.) 37 : $137-162$

Bayne, B. L., Worrall, C. M. (1980). Growth and production of mussels Mytilus edulis from two populations. Mar. Ecol. Prog. Ser, 3: 317-328

Berry, P. F., Schleyer, M. H. (1983). The brown mussel Perna perna on the Natal coast, South Africa: utilization of available food and energy budget. Mar. Ecol. Prog. Ser. 13: 201-210

Coughlan, J. (1969). The estimation of filtering rate from the clearance of suspensions. Mar. Biol. 2: 356-358

Doetsch, R. N., Cook, T. M. (1973). Introduction to bacteria and their ecobiology. Univ. Park Press, Baltimore

Grant, W. S., Cherry, M. I. (1985). Mytilus galloprovincialis Lmk. in Southern Africa. J. exp. mar. Biol. Ecol. 90: 179-191

Hildreth, D. I. (1980). Bioseston production by Mytilus edulis and its effect in experimental systems. Mar. Biol. 55: 309-315

Hobbie, J. E., Daley, R. T., Jasper, S. (1977). Use of nuclepore filters for counting bacteria by epifluorescence microscopy. Appl environ. Microbiol. 33: 1225-1228

Joint, I. R., Morris, R. J. (1982). The role of bacteria in the turnover of organic matter in the sea. Oceanogr. mar. Biol. A. Rev. 20: 65-118

Jørgensen, C. B. (1960). Efficiency of particle retention and rate of water transport in undisturbed lamellibranchs. J. du Conseil 26: 94-116

Jørgensen, C. B. (1975a). Comparative physiology of suspension feeding. A. Rev. Physiol. 37: 57-79

Jørgensen, C. B. (1975b). On gill function in the mussel, Mytilus edulis L. Ophelia 13: 187-232

Kiørboe, T., Møhlenberg, F. (1981). Particle selection in suspension-feeding bivalves. Mar. Ecol. Prog. Ser. 5: 291-296

Lancelot, C., Billen, G. (1984). Activity of heterotrophic bacteria and its coupling to primary production during the spring bloom in the southern bight of the North Sea. Limnol. Oceanogr 29: 721-730

Linley, E. A. S., Newell, R. C., Bosma, S. A. (1981). Heterotrophic utilisation of mucilage released during fragmentation of kelp (Ecklonia maxima and Laminaria pallida). I. Development of microbial communities associated with the degradation of kelp mucilage. Mar. Ecol. Prog. Ser. 4: $31-41$

Lucas, M. I. (1986). Decomposition in pelagic marine ecosystems. J. Limnol. Soc. sthn Afr. 12 (1 \& 2): 99-122

Luria, S. E. (1960). The bacterial protoplasm: composition and organisation. In: Gunsalus, I. C., Stanier, R. Y. (ed.) The bacteria, Vol. I. Academic Press, New York, p. 1-34

Møhlenberg, F., Ruisgård, H. U. (1978). Efficiency of particle retention in 13 species of suspension feeding bivalves. Ophelia 17 (2): 239-246

Monar, I. (1972). Analysenautomat zur simultanen Mikrobestimmung von $\mathrm{CH}$ und N. Mikrochim. Acta: 784-806

Newell, R. C. (1965). The role of detritus in the nutrition of two marine deposit-feeders, the prosobranch Hydrobia ulvae and the bivalve Macoma balthica. Proc. zool. Soc. Lond. 144: 25-45

Painting, S. J., Lucas, M. I., Stenton-Dozey, J. M. E. (1985). 
Biomass and production of bacterioplankton in Prydz Bay, Antarctica: phytoplankton, detritus and bacterial relationships. S. Afr. J. antarct. Res. 15: 42-52

Palumbo, A. V., Ferguson, R. L. (1978). Distribution of suspended bacteria in the Newport River estuary, North Carolina. Estuar. coast. mar. Sci. 7: 521-529

Schleyer, M. H. (1981). Microorganisms and detritus in the water column of a subtidal reef of Natal. Mar. Ecol. Prog. Ser. 4: 307-320

Seiderer, L. J., Davis, C. L., Robb, F. T., Newell, R. C. (1984). Utilisation of bacteria as a nitrogen resource by kelp-bed mussel Choromytilus meridionalis. Mar. Ecol. Prog. Ser. 15: $109-116$

Seiderer, L. J., Newell, R. C. (1985). Relative significance of phytoplankton, bacteria and plant detritus as carbon and nitrogen resources for the kelp bed filter-feeder Choromytilus meridionalis. Mar. Ecol. Prog. Ser. 22: 127-139

Stuart, V., Klumpp, D. W. (1984). Evidence for food-resource partitioning by kelp-bed filter feeders. Mar. Ecol. Prog. Ser. 16: $27-37$
Vahl, O. (1972). Efficiency of particle retention in Mytilus edulis L. Ophelia 10: 17-25

Widdows, J. (1978). Combined effects of body size, food concentration and seston on the physiology of Mytilus edulis. J. mar. biol. Ass. U. K. 58: 125-142

Widdows, J., Donkin, P., Salkeld, P. N., Cleary, J. J., Lowe, D. M., Evans, S. V., Thompson, P. E. (1984). Relative inportance of environmental factors in determining physiological differences between two populations of mussels (Mytilus edulis). Mar. Ecol. Prog. Ser. 17: 33-47

Williams, L. G. (1982). Mathematical analysis of the effects of particle retention efficiency on determination of filtration rate. Mar. Biol. 66: 171-177

Wright, R. T., Coffin, R. B., Ersing, C. P., Pearson, D. (1982). Field and laboratory measurements of bivalve filtration of natural marine bacterioplankton. Limnol. Oceanogr. 27 (1): $91-98$

This article was submitted to the editor; it was accepted for printing on January 23, 1987 